\title{
A estratificação social na América Latina representada nos espaços domésticos e simbólicos: uma análise comparativa dos filmes Que horas ela volta? e Roma
}

Tatiana Martins Montenegro ${ }^{1}$

Rogério de Souza Sergio Ferreira²

\footnotetext{
${ }_{1}^{1}$ Doutoranda em Estudos Literários (Universidade Federal de Juiz de Fora). Pós-graduada em Televisão, Cinema e Mídias Digitais (Universidade Federal de Juiz de Fora). Professora do curso de Comunicação Social (Centro Universitário Estácio de Juiz de Fora). email: tatiana.marmon@yahoo.com.br

${ }^{2}$ Doutor em Ciência da Literatura (Universidade Federal do Rio de Janeiro). Pós-doutor na Universidade da Califórnia. Professor Associado na Faculdade de Letras (Universidade Federal de Juiz de Fora). email: rogeriossferreira@gmail.com
} 


\section{Resumo}

O presente artigo realiza uma análise fílmica e comparativa de Que horas ela volta? e Roma, obras cinematográficas que apresentam um recorte temporal de relevância político-social nos países Brasil e México, respectivamente. Ambas as narrativas contemplam o cotidiano de uma empregada doméstica, figura capaz de ser tão relevante e, ao mesmo tempo, tão invisível nos países latino-americanos. Os contrastes sociais e os elementos simbólicos representados nos espaços domésticos dos filmes são tratados aqui de forma a identificar semelhanças e diferenças entre as obras. Diante de tal investigação, é possível afirmar que Que horas ela volta? e Roma implicam em um retrato da sociedade latinoamericana, sendo a empregada doméstica um ponto de convergência entre ambas as culturas, bem como um vestígio das sociedades patriarcais e escravocratas ocidentais.

Palavras-chave: Empregada doméstica; Estratificação social; Que horas ela volta?; Roma.

\section{Abstract}

This paper offers a comparative and cinematographic analysis of The Second Mother and Rome. These movies present a relevant social-political time-lapse in Brazil and Mexico, respectively. Both narratives contemplate the daily life of a housekeeper, someone capable of being so relevant and so invisible at the same time in Latin American Countries. The social contrasts and the symbolical elements shown at the home environments of both films are approached in this study to identify similarities and differences between the works. This investigation allows us to affirm that The Second Mother and Rome result in a picture of Latin American Society, being the housekeeper a point of convergence between both cultures, as well as a trace of Western patriarchal and slave societies.

Keywords: Housekeeper; Social stratification; The Second Mother; Rome. 
Introdução

O cinema pode ser considerado um recurso capaz de traduzir a realidade de uma determinada sociedade, projetando problemas e evidenciando questões culturais, socioeconômicas e políticas que necessitam ser vislumbradas com maior atenção. Por meio dos elementos técnicos e narrativos de uma obra, o espectador pode ser levado a adquirir crenças que reforçam estereótipos ou é capaz de rompê-las. Os filmes enfatizam ou desmistificam a construção de status, dentre outros aspectos simbólicos que formam o entendimento acerca de um grupo social. Dependendo do modo como é pensada e produzida, a sétima arte pode contribuir na desconstrução de normas e sistemas sociais que não mais se aplicam atualmente, resultando em importantes discussões que perpassam público e crítica.

É o que propõem os filmes latino-americanos Que horas ela volta? e Roma, produções provenientes do Brasil e México, respectivamente. Escrito e produzido pela cineasta brasileira Anna Muylaert, a obra fílmica nacional, lançada em 2015, aborda as vivências de uma empregada doméstica que presta serviços aos patrões pertencentes à classe média alta brasileira. Além dos conflitos cotidianos que apontam para as desigualdades sociais do país, Que horas ela volta? apresenta temáticas que envolvem maternidade, criação terceirizada, cenário político, invisibilidade social, bem como faz uso de recursos estéticos e poéticos a fim de provocar no espectador um conglomerado de reações.

A proposta é constituída de elementos bastante semelhantes ao longametragem escrito e produzido pelo mexicano Alfonso Cuarón e lançado em 2018. Roma aborda as experiências de uma trabalhadora doméstica nos anos de 1970 e suas relações com os problemas da casa. Em ambas as obras fílmicas, o enfoque é direcionado às mulheres pobres, que não são brancas e que exercem funções comuns, ao contrário do que é frequentemente percebido em grande parte dos filmes comerciais. Nestes, os personagens centrais são, em sua maioria, líderes, intelectuais, cientistas ou heróis, sobretudo do gênero masculino e dentro dos padrões de beleza.

Considerando os inúmeros pontos de convergência entre Que horas ela volta? e Roma, o presente artigo tem como objetivo realizar uma análise comparativa entre as produções, propondo uma reflexão acerca do histórico político e social representado nas tramas, bem como uma investigação dos aspectos metafóricos que compõem as obras. Deste modo, será realizada uma revisão de literatura, bem como uma pesquisa documental e análise fílmica. Para tanto, de início, o trabalho apresenta e discute separadamente as obras fílmicas e os elementos principais de cada uma delas. Por fim, os filmes são analisados em conjunto, onde serão identificadas suas distinções e similaridades. 
1. Que horas ela volta?: um retrato da sociedade brasileira contemporânea e seus vestígios do passado

A produção brasileira lançada na segunda década do século XXI narra uma trama que ocorre no mesmo período. Na estreia, Que horas ela volta? foi exibido em mais de trinta países e acumula premiações internacionais, como o Prêmio do Público no Festival Berlinale, na Alemanha, e o Prêmio Especial do Júri no Festival de Sundance, nos Estados Unidos. Na visão de Magno (2016), a repercussão positiva se deve ao fato de haver uma complexidade disfarçada de uma trama aparentemente prosaica. Segundo a pesquisadora, "a história é simples, mas a ideia e a elaboração do roteiro não" (MAGNO, 2016: 165).

A personagem central da história chama-se $\mathrm{Val}$, uma pernambucana que deixou a filha ser criada por parentes para ir à busca de melhores condições de vida no Sudeste do país. Val trabalha há mais de dez anos para uma família economicamente privilegiada, fazendo as vezes de empregada e babá. Para Lana (2016:126) "as trabalhadoras domésticas, além de realizarem tarefas fisicamente exaustivas [...] também precisam transmitir a sensação de cuidado e conforto, incumbências emocionais".

Segundo Ferraz (2013), a criação terceirizada somada ao serviço doméstico ocorre da necessidade da mulher/esposa/mãe de diminuir a sobrecarga de uma jornada de trabalho dupla, utilizando para isso o auxílio uma mão-de-obra barata. Ao mesmo tempo, segundo a autora, esta prática retira do Estado a responsabilidade de investimentos na construção de espaços institucionais para as crianças, como as creches (FERRAZ, 2013). A respeito da força de trabalho doméstico, Souza (2009) ressalta:

Como ela não encontra emprego no setor produtivo que pressupõe uma relativa alta incorporação de conhecimento técnico ou 'capital cultural', só pode ser empregada enquanto mero 'corpo', ou seja, como mero dispêndio de energia muscular. É desse modo que essa classe é explorada pelas classes média e alta: como 'corpo' vendido a baixo preço [...] (SOUZA, 2009:23-24).

O valor inferior da mão-de-obra de uma doméstica se reflete na qualidade da sua condição de sobrevivência. No filme, o dormitório ocupado pela funcionária na residência, localizada no bairro Morumbi, em São Paulo, trata-se de um puxadinho, local separado da casa principal e próximo à cozinha. De acordo com Almeida et al (2017: 7) "essa definição espacial é acompanhada de uma indefinição entre o tempo de trabalho e o tempo para si, entre ser um membro da família ou um empregado". 
A fim de demonstrar as condições da protagonista, a maior parte dos acontecimentos é notada pela perspectiva da cozinha, local em que a empregada passa a maior parte do tempo. Os planos abertos e o foco na porta da cozinha são repetidos em diferentes contextos. Isso ajuda o espectador a entender que o filme é narrado sob o ponto de vista de Val e é um artifício eficiente pra criar a sensação de rotina (Figura 01).

No pequeno quarto onde dorme, é possível observar a doméstica pelas grades da janela, fazendo referência a uma espécie de aprisionamento (Figura 02). A observação dialoga com a afirmação de Scherdien (2018), que diz que o filme faz o espectador se atentar para as desigualdades sociais do país e perceber os vestígios da escravidão no cotidiano atual.

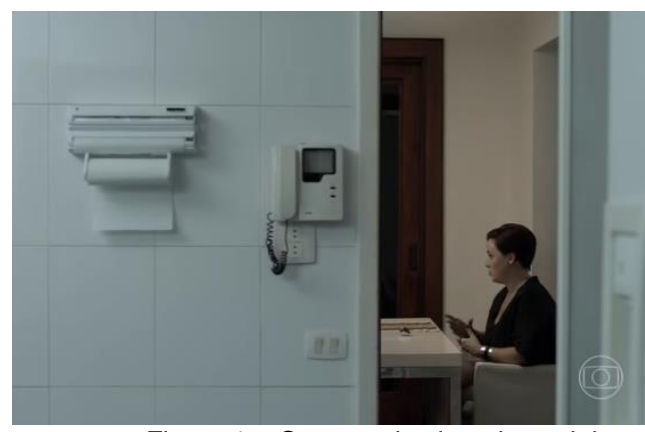

Figura 1 - O ponto de vista da cozinha.

Fonte: Que horas ela volta, 2015.

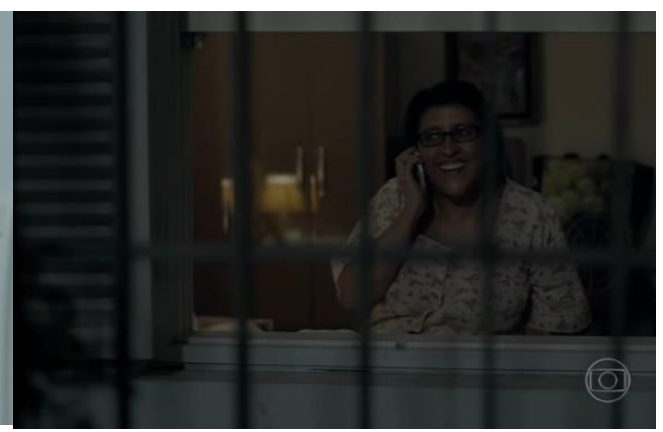

Figura 2 - Val em seu quarto: grades. Fonte: Que horas ela volta, 2015.

A família para qual Val trabalha é composta por um casal, Bárbara e Carlos, e o filho adolescente, Fabinho. Embora exista uma segregação física e social entre a empregada e os outros membros da casa, a relação estabelecida entre a funcionária e o garoto é de proximidade e afetividade. Para Hahner (2013), a ligação entre a serviçal e o filho da patroa representa uma realidade que perpassa gerações, herança dos tempos de escravidão, quando as esposas dos senhores ricos transmitiam às escravas ou mães que viviam em condições precárias o exercício de amamentação da sua cria. A aproximação com o filho da patroa, nesse filme, segundo Almeida et al (2017), também pode ser vista como uma forma de compensação, dado que a empregada se fez ausente na criação da única filha, com o objetivo de sustentá-la.

O relacionamento de Val com os pais de Fabinho, embora cordial, apresenta um distanciamento velado, onde a hierarquia torna-se estabelecida pelas de falas, ações e ocupações espaciais. Os patrões são chamados pela empregada por meio das formas de tratamento "doutor Carlos" e "dona Bárbara". Estes, por sua vez, afirmam a Val que ela "é praticamente da família", entretanto, no close dos registros fotográficos familiares, observa-se que a empregada aparece em segundo plano (Figura 03). A não utilização 
dos espaços nobres da casa por Val, como a piscina, também é um fator que demarca o lugar da funcionária, o que pode ser percebido no Figura 04, que demonstra a doméstica não ultrapassando os limites físicos estabelecidos naquele microcosmo.

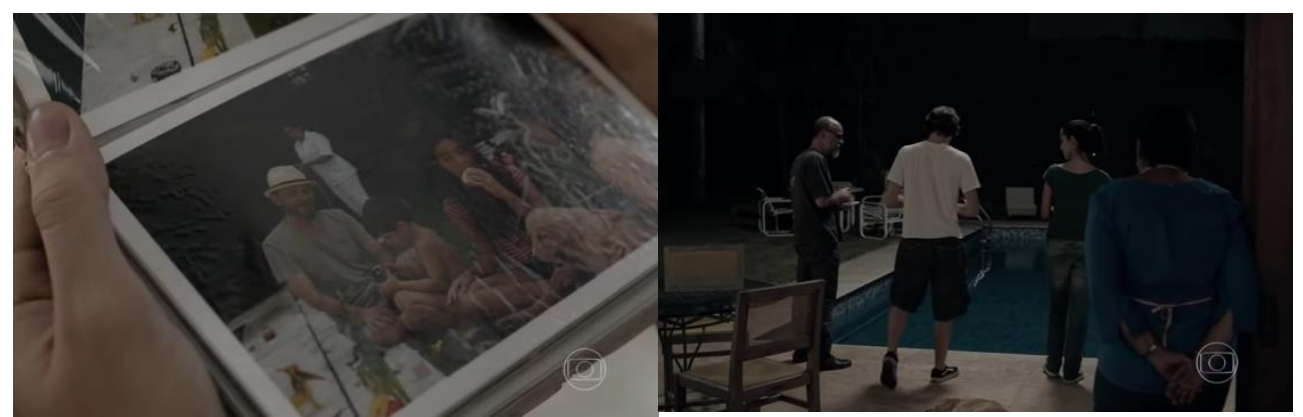

Figura 3 - Foto com Val, de branco, ao fundo. Fonte: Que horas ela volta, 2015.

Figura 4 - Distância de Val da piscina. Fonte: Que horas ela volta, 2015.

Existem, portanto, inúmeras barreiras que separam Val daquele núcleo familiar. Por diversas vezes, a patroa demonstra um comportamento passivo-agressivo, fazendo falsos elogios à empregada - como, por exemplo, quando Val lhe dá um conjunto de xícaras em seu aniversário e Bárbara desdenha do presente por ser de qualidade inferior. Durante a comemoração da data, a empregadora solicita a Val o uso de xícaras da Suécia e afirma que os produtos dados como presentes pela doméstica serão levados para a casa no Guarujá. Desta forma, embora diga a Val que ela é quase da família, não demonstra o mesmo nas atitudes. Bárbara representa, portanto, a hipocrisia da classe média privilegiada.

Acostumada com o tratamento, a protagonista naturalizou as relações vivenciadas no ambiente doméstico, concordando integralmente com a sua condição e o seu lugar na casa e na família. De acordo com Bourdieu (2008), os capitais cultural, econômico e político de um indivíduo relacionam-se diretamente à formação do seu habitus, isto é, o modo pelo qual o ser humano se insere e se percebe na sociedade a qual pertence. Val, nesse caso, tem ciência do lugar que ocupa e respeita os limites que Ihe foram impostos.

A grande virada na narrativa ocorre quando Jéssica, filha de Val, se muda para São Paulo e passa a viver na casa dos patrões da mãe, alterando a rotina e despertando os mais variados sentimentos nos moradores do local. Por não ter sido criada por Val, Jéssica não compartilha das mesmas crenças e valores da mãe. Ao contrário da doméstica, a filha não aceita as regras implicitamente estabelecidas e, ao rompê-las, coloca em xeque a estabilidade da hierarquia de classes naquele ambiente. 
A razão pela qual a jovem se muda para São Paulo é o objetivo de ser aprovada no vestibular. Jéssica deseja cursar arquitetura na Universidade de São Paulo, considerada uma das instituições públicas mais concorridas do Brasil e também a opção de Fabinho. Quando chega na casa dos patrões da mãe e compartilha a pretensão, percebe-se que a reação de Bárbara é de surpresa e ceticismo, dado que Jéssica cursou o ensino básico de maneira precária no Nordeste do país.

Ao longo da narrativa, todavia, a filha de Val demonstra características como inteligência, esperteza e inconformidade com o lugar que the foi dado na casa. "Não pode isso, não pode aquilo. Tá escrito em livro?", questiona Jéssica à mãe. Lana (2016) afirma que Jéssica representa o perfil do jovem brasileiro nascido e crescido no começo dos anos 2000, um ser pleno de sinceridade; que busca a independência; investe na própria educação; ausente de crenças limitantes e que desfruta das oportunidades oferecidas pelo governo brasileiro nas primeiras décadas do século XXI (LANA, 2016). Para Almeida et al (2017),

a produção do filme ocorre em um momento em que as políticas públicas se expandem para a proteção social e influenciam uma nova geração de jovens construída a partir de um ganho de auto-estima das classes trabalhadoras. Demonstrando o quanto o cinema está em sintonia com as mudanças sociais, e o quanto é rápido em sua representação dessas mudanças (ALMEIDA et al, 2017:17).

As atitudes de Jéssica se opõem ao comportamento dos menos privilegiados e mestiços que ascendiam no século XIX, no Brasil. De acordo com Freyre (2012), estes necessitavam usar do excesso de simpatia e agradabilidade para se inserir na sociedade.

O tratamento recebido pela estudante na casa, cenário central da narrativa, despertou não só a incompreensão por parte de Val. Em diversos momentos, Bárbara demonstrou incômodo e insatisfação com o comportamento de Jéssica - que, diferentemente da mãe, conseguia ultrapassar as barreiras espaciais do local, como utilizar a piscina e o quarto de hóspedes. A conquista de um melhor aproveitamento do espaço físico se deve ainda ao fato de Carlos ter se sentido atraído pela jovem. Em inúmeras situações, o marido de Bárbara demonstra interesse por Jéssica, chegando a assediá-la - ação que remete, segundo Lana (2016), aos tempos de escravidão, quando os senhores de engenho procuravam as criadas para satisfazer seus interesses sexuais.

O ponto alto da narrativa se dá quando Jéssica é aprovada no vestibular (ao contrário de Fabinho), superando as expectativas dos demais personagens. É neste momento que Val rompe com suas crenças limitantes. Ao reconhecer a competência da 
filha, a doméstica quebra as regras que sempre acatou e entra na piscina não só como uma espécie de comemoração, mas como um momento de catarse, isto é, uma tomada de consciência e uma quebra de paradigmas. Val, então, se sente segura e audaciosa devido à ruptura com a sua condição anterior.

Diante do fracasso no vestibular, Fabinho decide estudar na Austrália. A ausência do jovem na casa somada à vitória de Jéssica resultou na mudança emocional e espacial da doméstica, que decide sair da casa dos patrões e, em seguida, pedir demissão, ampliando o sentimento de liberdade. Por fim, Jéssica revela ter um filho e confessa à mãe que o deixou no Nordeste em busca de melhores condições de vida, assim como Val havia feito no passado. Ao solicitar a vinda do neto a São Paulo e dizer à filha que the ajudaria a cuidar da criança, a ex-doméstica não só encerra o ciclo de ausência materna como adquire a crença do otimismo em si, na filha e no país ${ }^{3}$.

\section{Roma: um retrato da sociedade mexicana do passado e seus vestígios no presente}

O longa-metragem mexicano Roma, distribuído originalmente pela Netflix, foi a primeira obra fílmica de uma plataforma streaming a concorrer ao Oscar. Em 2019, venceu a premiação nas categorias de Melhor direção, Melhor filme estrangeiro e Melhor fotografia. Além disso, foi premiado em outros eventos relevantes, como o Festival Internacional de Cinema de Veneza e o Globo de Ouro. Foi aclamado pela crítica por ser considerado uma obra de arte e, segundo Nájera (2019: 38, tradução nossa), por deixar "em evidência controvérsias sociais e políticas que persistem em nossas sociedades atuais".

Cleo, protagonista da narrativa, é uma empregada doméstica de origem indígena que presta serviços à uma família de classe média que reside em Roma, bairro nobre da Cidade do México. A história, que se passa na década de 1970, tem início com a apresentação da rotina exaustiva de Cleo, responsável por cuidar não só dos afazeres da casa, mas de uma família composta por três adultos, quatro crianças e um cachorro. Sua rotina tem início antes dos patrões acordarem e termina após eles irem dormir.

A fim de dar ênfase ao cotidiano da empregada, os primeiros momentos do filme são dedicados à demonstração de suas numerosas funções. São mais de seis minutos acompanhando Cleo em suas tarefas, o que tende a gerar certa angústia no espectador. Desses, quatro minutos são de câmera parada, com o close na limpeza do piso, sem mostrar a fisionomia da doméstica (Figura 05). Ainda considerando os

${ }^{3}$ Em 2013, no Brasil, foi estabelecida a PEC das Domésticas, um conjunto de leis que formaliza o trabalho dessas profissionais. As normas complementares foram estabelecidas em 2015, ano de lançamento do filme. 
aspectos técnicos, o uso de panorâmica enquanto Cleo arruma a casa (Figura 06) contribuiu para que o público compreendesse, logo de início, o lugar da personagem no espaço doméstico.

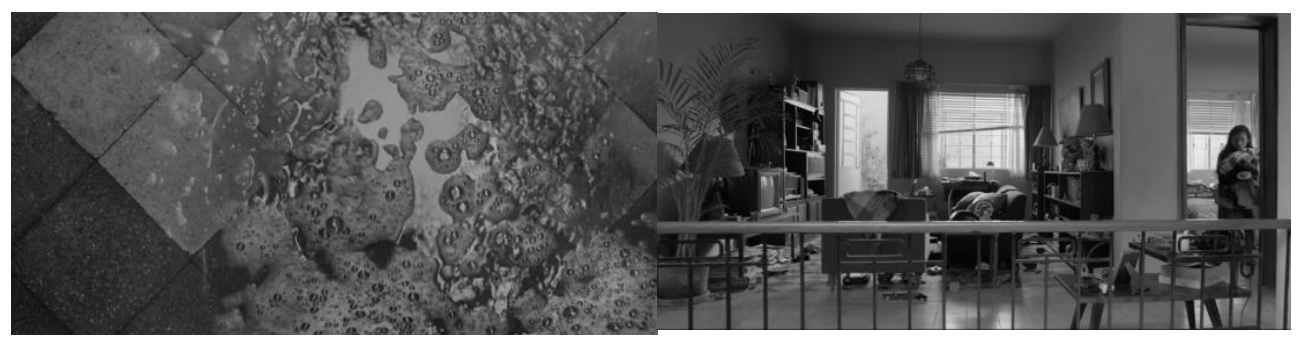

Figura 5 - Limpeza do piso feita por Cleo.

Figura 6 - Cleo organizando a casa.

Fonte: Roma, 2018.

Fonte: Roma, 2018.

Não somente nos momentos iniciais, mas em diversos outros trechos, observa-se um ritmo lento, com cenas longas e tempos de silêncio. Ao considerar a rotina acelerada das pessoas nos dias atuais (BAUMAN, 1998), o filme se opõe ao ritmo de vida dos indivíduos, podendo implicar em angústia por parte do espectador. Na visão de Brinkman-Clark (2018:70, tradução nossa) "o fato de que a câmera é fixa, que se move com tanta lentidão e que parece imutável antes dos movimentos de Cleo, torna possível para o espectador perceber um certo sentimento de confinamento". Outro fator que pode ser visto como aflitivo é o uso da fotografia em preto e branco durante toda a narrativa, característica incomum às produções fílmicas atuais, mas que se aplica ao contexto apresentado na trama.

Após mostrar as funções da doméstica, o diretor e roteirista Cuarón explica ao espectador, por meio da narrativa, de que forma se dá a interação de Cleo com os demais membros da casa - em especial, com os filhos dos patrões. Nota-se que a empregada é a responsável pelas funções cotidianas de fazê-los dormir e por despertálos. Além do cuidado diário, a protagonista mantém uma relação de afeto e proximidade com as crianças. No entanto, a consciência sobre a existência das diferenças sociais entre ambos é mantida. Brites (2007), em seus estudos antropológicos, questiona:

[...] se existe tanta intimidade e afeto entre as crianças e suas empregadas, como se reproduzem patroas adultas com um sentido tão forte de hierarquia? Como se separam esses mundos? Não é regra entre os patrões investigados um tratamento ríspido com suas empregadas. As crianças aprendem a distância social entre elas e as empregadas domésticas através de outras vias - informações subliminares, por exemplo, nos dizeres dos seus pais e na disposição de espaço. "Quarto de empregada", "banheiro de empregada", "dependência de empregada" são espaços de segregação, onde o respeito ensinado às crianças de classe 
média com as posses alheias desaparece (BRITES, 2007: 103).

As segregações espaciais são claramente percebidas em Roma, dado que Cleo dorme em um quarto separado da casa. A própria empregada também reforça às crianças suas diferentes disposições. Em uma cena onde elas sobem no terraço, área dos varais, para brincar (Figura 07), aos 10 minutos de filme Cleo logo as repreende: "não deveriam estar aqui em cima! Sua mãe não vai gostar!" (ROMA, 2018). Por meio desta fala, observa-se que a patroa impõe limites espaciais no ambiente doméstico e que Cleo procura os respeitar. Aliás, durante toda a narrativa, identifica-se que a empregada age dentro das normas que the foram condicionadas, um aspecto da formação do seu habitus (BOURDIEU, 2008).

Ainda na cena do terraço, outra situação sugere indiretamente a posição de inferioridade da protagonista. Enquanto lava as roupas, Cleo canta uma canção que toca no rádio e que diz: "Quando eu te disser que sou pobre / você nunca mais vai sorrir / eu gostaria de ter tudo / para colocar aos seus pés / mas eu nasci pobre / e você nunca me amará" (ROMA, 2018).

O Figura 08 apresenta mais uma situação cotidiana que expressa o lugar de Cleo tanto na casa, quanto na família. Enquanto todos assistem à TV na sala, hábito de lazer comum nos anos de 1970 (TUFTE, 1997), a empregada se senta no chão por não ter um lugar no sofá, ao mesmo tempo em que é abraçada por uma das crianças. Desta forma, emocionalmente, Cleo pertence ao núcleo familiar -, todavia, é desprivilegiada em comparação aos outros membros do local.

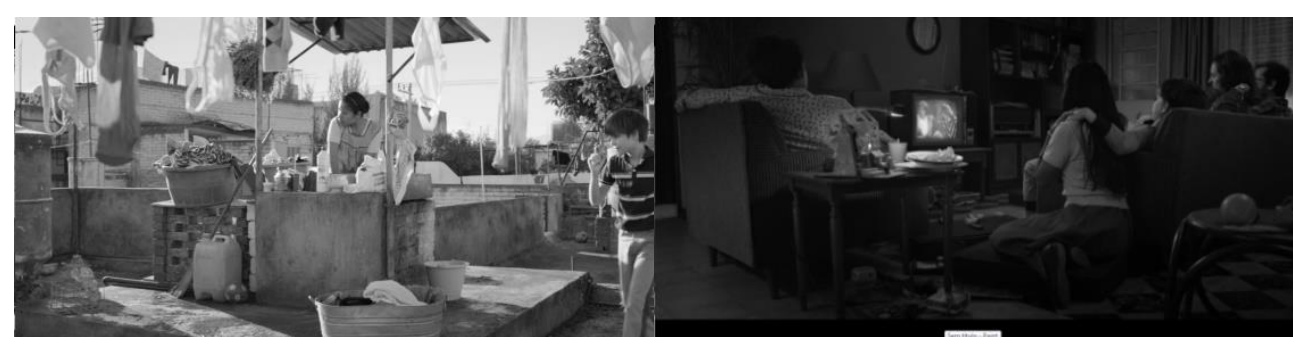

Figura 7 - Cleo e as crianças no terraço.

Figura 8 - O lugar de Cleo na casa e na família.

Fonte: Roma, 2018.

Fonte: Roma, 2018.

A virada na história se dá quando a protagonista sai da sua zona de conforto ao descobrir que está grávida. A relação com o pai da criança, um lutador de artes marciais, também desprivilegiado economicamente, se deu de maneira rápida e resultou em um desamparo por parte do homem para com a jovem e o bebê. Ao mesmo tempo, Sofia, patroa de Cleo, é abandonada pelo marido, que negligencia a família em prol de um romance extraconjugal. 
Neste momento, as emoções são percebidas de forma semelhante por ambas as personagens. Cleo e Sofia, embora estejam em universos socioeconômicos distintos, compartilham da mesma dor: o desamparo da parte dos pais dos seus filhos e o temor diante da condição de cuidarem sozinhas dos seus descendentes, o que Scarpellini e Carlos (2011: 4) chamam de "monoparentalidade feminina". Em uma cena na qual Sofia chega em casa alcoolizada e desnorteada frente à decepção com o marido, se dirige a Cléo e diz: "Estamos sozinhas. Digam o que nos disserem, nós, mulheres, estamos sempre sozinhas" (ROMA, 2018).

A situação de ambas desconstrói a idealização estrutural familiar romana, na qual o homem é a figura do chefe de família, isto é, aquele que atua como esposo, pai e protetor do núcleo, sustentando o modelo do patriarcado (PEREIRA, 1997). Esse molde começou a ser diluído, segundo Scarpellini e Carlos (2011), nos anos 1960. Com os movimentos feministas, as mulheres adquiriram a oportunidade de se libertar de relações conjugais opressoras - todavia, essa realidade ainda era nova para o momento histórico no qual a trama se passa. Apesar disso, Nájera (2019: 39, tradução nossa) acredita que a narrativa dialoga com as lutas feministas da atualidade, pois "[...] não aborda apenas o trabalho doméstico, e como esse trabalho é sempre levado adiante pelas mulheres; também introduz o problema da maternidade precoce e do tráfego solitário"4.

A compaixão e solidariedade representadas no filme estão relacionadas, portanto, à maternidade e ao abandono do par romântico. Nesse sentido, a empatia de Sofia com a condição de Cleo fez com que ela auxiliasse a empregada durante o prénatal, tanto no acompanhamento de exames como na compra de artigos para bebês. Entretanto, a empregada não deixou de ser cobrada pela execução das suas tarefas no ambiente doméstico.

Ao visitar uma loja de berços com Teresa, mãe de Sofia, Cleo e a senhora são surpreendidas com um ataque a tiros, decorrente de uma manifestação estudantil que acontecia simultaneamente. O protesto dos estudantes em defesa dos presos políticos apresentado na narrativa aconteceu, de fato, no México, em 1971, e ficou conhecido como a Revolução de Corpus Christi (BERNARDI, 2010). O filme faz, então, uma crítica social por meio da demonstração de eventos paralelos aos problemas políticos do país: ou seja, enquanto a classe média vivia seus próprios conflitos e dramas em seu mundo particular, uma das maiores chacinas estava acontecendo no México, e em momento algum os personagens abordaram essa crise.

\footnotetext{
${ }^{4}$ Criação de um filho pela mãe sem a presença paterna.
} 
No momento do ataque à loja, Cleo vê o pai do seu filho armado no local e, logo em seguida, sua bolsa amniótica estoura. Após enfrentar momentos de turbulência até chegar ao hospital, Cleo finalmente é atendida e, ao dar à luz uma menina, descobre que o bebê nasceu natimorto. Esta é uma das únicas cenas em que a protagonista esboça uma reação energética e expressiva (Figura 09), dado que a doméstica esboça passividade na maioria das situações, inclusive nas mais aflitivas. Sobre a personagem, Zabalbeascoa (EL PAÍS, 2018) diz: "O resto é uma mulher que cala, mas abraça. Que muito raramente deixa escapar um suspiro, um lamento. De censuras, nem se fala". Ademais, durante o tempo que a jovem se mantém no hospital, observa-se a pouca atenção dos profissionais do local para com a doméstica, situação comuns em instituições públicas da América Latina.

No fim da narrativa, a família viaja para a cidade praiana de Tuxpan. A intenção de Sofia era escapar dos problemas que circulam na casa; oferecer espaço para o exmarido retirar seus pertences do local e, ao mesmo tempo, contar aos filhos sobre o divórcio. Cleo, por sua vez, viajou no papel de babá, ao passo que também superava a perda do seu bebê. Após receber a notícia da nova configuração familiar, as crianças reagiram com pesar, causando um clima geral de consternação. Esses sentimentos são claramente percebidos na cena contrastante em que todos tomam sorvete enquanto um homem e uma mulher celebram o casamento (Figura 10). A cena demonstra ainda que, embora Cleo participe dos momentos em família, a distância entre eles se mantém e se reflete espacialmente, uma vez que a jovem se mantém de pé enquanto os patrões estão sentados.

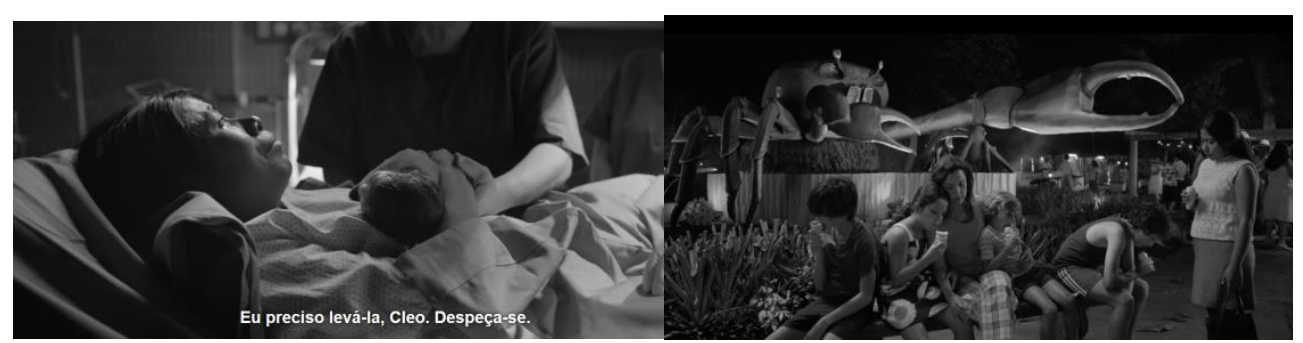

Figura 9 - Cleo e o bebê natimorto.

Figura 10 - Cleo de pé e os patrões sentados.

Fonte: Roma, 2018.

Fonte - Roma, 2018.

O ápice da narrativa ocorre no momento em que a empregada cuida das crianças na praia e duas delas se afogam. Na ausência de Sofia, Cleo, mesmo tendo deixado claro por diversas vezes que não sabia nadar, entra no mar para salvá-las. Enfrentar o medo da água com o propósito de ajudá-las fez com que a personagem se libertasse, a ponto de confessar que não desejava o bebê que esperava. De acordo com 
Gonçalves (2015), a negação da gravidez pode vir em decorrência do desamparo sofrido pela mãe, situação compatível com a de Cleo.

Assim, o abandono uterino denuncia o abandono parental sofrido por essas mulheres que passam por essa experiência de desconhecimento da própria gestação. Para acolher é preciso ter sido acolhido, uma incapacidade de acolher outro ser dentro de si, se transforma em um abandono uterino, repetindo o abandono e o mal acolhimento sofrido em vida. (GONÇALVEZ, 2015: 126)

A personagem, então, transfere $o$ amor da sua filha para os filhos de Sofia, e a atitude da protagonista é reconhecida prontamente pela patroa e as crianças, que sobreviveram. $\mathrm{O}$ acolhimento recebido por Cleo, naquele momento, faz criar no espectador a expectativa de que ela se torne um membro mais valorizado no núcleo o qual pertence. Todavia, ao retornarem a casa em Roma e ao cotidiano, observa-se que a protagonista permanece no mesmo lugar que ocupava anteriormente. Na perspectiva de Guarnica (2019), isso ocorre porque o propósito dessa obra fílmica foi apresentar uma narrativa compatível com a realidade, onde inúmeras domésticas, sobretudo na América Latina, cometem atos heroicos diariamente e se mantêm na invisibilidade. Cleo não lutou somente contra a maternidade, mas também contra uma civilização constituída de hostilidade e adversão.

\section{Análise comparativa}

Diante das análises fílmicas e das características apresentadas até aqui, foi possível identificar elementos semelhantes, tratando-se das produções Que horas ela volta? e Roma. As analogias existem desde a idealização do roteiro, tendo em vista que tanto Muylaert quanto Cuarón se inspiraram nas suas próprias histórias de vida para a composição da narrativa. Ambos cresceram com a figura de uma empregada doméstica e, em dado momento, notaram que essas nunca tiveram visibilidade e muito menos 0 protagonismo compatível com o seu merecimento. A seguir, serão elencados os principais pontos de convergência e divergência entre as obras.

\subsection{O lugar da empregada na casa dos patrões: limites e relações de trabalho}

Val e Cleo são personagens com origens semelhantes. Ambas saíram das suas regiões em busca de sobrevivência e melhores oportunidades de trabalho. Val representa milhares de brasileiros que migram internamente pelo país devido à desigualdade social. De acordo com Santos (2010), 1,5 milhões de nordestinos, em 
média, migraram do Nordeste para o Sudeste ${ }^{5}$ na segunda metade do século XX. 0 mesmo processo, segundo Dias (2012), ocorreu com os povos indígenas mexicanos. Diante das condições de vida precárias, boa parte desta população migrou para a capital do país, Cidade do México. Todavia, Horacio (2007 apud Dias, 2012) salienta que a negligência com este grupo social se manteve.

Os indígenas na Cidade do México são povos e populações que se mantiveram ocultos ou disfarçados, sem políticas de governo específicas para eles. Em muitos aspectos, também continuam sendo invisíveis para a maioria dos cidadãos do Distrito Federal (HORACIO, 2007: 61 apud DIAS, 2012:185).

Esses foram, portanto, os motivos que levaram as migrantes Cleo e Val a oferecer mão-de-obra barata nas metrópoles que decidiram viver. Outra característica de origem em comum é o fato de fazerem parte de grupos considerados minoritários: são mulheres, pobres e não são brancas - além de não se adequarem aos padrões de beleza impostos pela sociedade, aspectos que reforçam a invisibilidade social de ambas.

Ao decidirem trabalhar como empregadas domésticas, tanto a protagonista brasileira quanto a mexicana aceitaram viver sob os regimentos estabelecidos por seus patrões, que minimizam os seus valores na sociedade civil e as colocam em uma posição de submissão. O fato de os quartos de dormir serem separados da casa dos patrões e apresentarem condições precárias delimita seus respectivos lugares em suas respectivas famílias.

Outro aspecto que demarca a posição de ambas na casa é o uso do avental (Figuras 11 e 12), que funciona como uma espécie de uniforme e é utilizado pelas duas personagens nas primeiras cenas dos filmes, com o propósito de salientar a estratificação social presente nos locais. O uniforme, para Peres e Barreira (2003), pode ser considerado

um tipo específico de vestimenta para determinada categoria de indivíduos e identifica-os como pertencentes a um grupo ou a uma instituição. Caracterizando a figura de quem o está usando, o uniforme funciona como objeto disciplinador, uma vez que padroniza as atitudes e comportamentos de quem 0 veste [...] (PERES; BARREIRA, 2003: 57).

As figuras abaixo retratam ainda o espaço de trabalho das domésticas, que é compartilhado com outros funcionários, como faxineiras e motoristas. Em ambas as cenas, observa-se que os serviços prestados não se limitam aos patrões, pois Cleo e

\footnotetext{
${ }^{5}$ Especialmente São Paulo e Rio de Janeiro.
} 
Val também cozinham para os demais colaboradores da casa. Além de ser um espaço de trabalho, para uma doméstica, a cozinha se torna um dos seus principais ambientes de socialização.

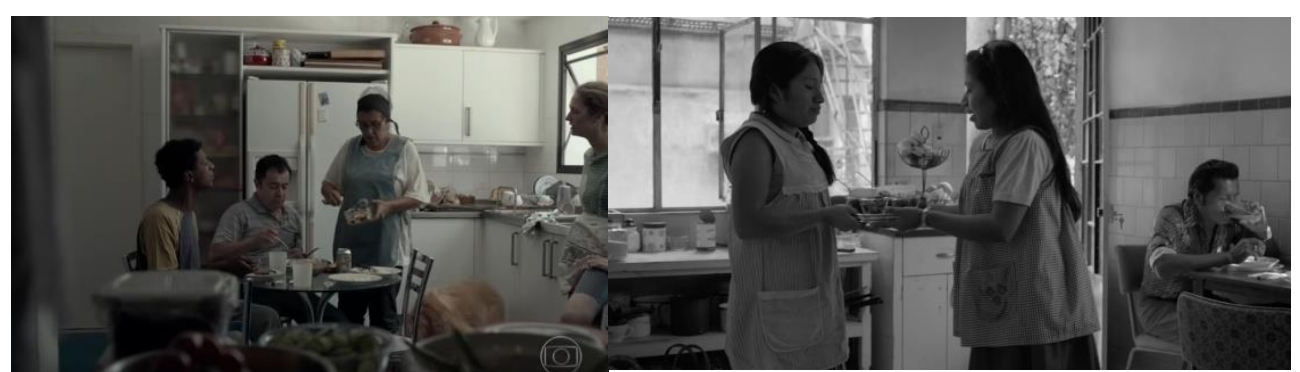

Figura 11 - Val e os demais empregados.

Figura 12 - Cleo e os demais empregados.

Fonte: Que horas ela volta?, 2015.

Fonte: Roma, 2018.

Cleo, assim como Val, desenvolve relações de amizade e intimidade com outra doméstica. No caso da mexicana, embora fale espanhol, se comunica com a amiga por meio de um dialeto próprio. Segundo Dias (2012), o México possui 62 idiomas indígenas e $8 \%$ da população utilizam-nos na comunicação interpessoal.

Mesmo que, em poucas cenas, ambas aparentam ter vida social (Figuras $13 \mathrm{e}$ 14), no entanto, Cleo chega a se envolver amorosamente com um rapaz, ao contrário de Val, que não estabelece relações conjugais na narrativa. Na obra brasileira, um sujeito aborda a amiga de Val em uma festa enquanto que a pernambucana é ignorada pelos demais homens, o que demonstra que sua invisibilidade rompe os muros da casa no Morumbi. Cleo, apesar de ter se relacionado com Fermín, foi negada pelo mesmo após ter engravidado. Ao dizer à jovem que não assumiria a criança, insultou-a, chamando-a de "faxineira de merda". Desta forma, mesmo que de formas diferentes, ambas sofreram rejeição no que se refere à figura masculina.

No que tange às relações de trabalho, em ambos os filmes nota-se claramente as relações de poder durante as refeições. $O$ ato de servir aos patrões e não ter um lugar à mesa (Figuras 15 e 16) reforça a estratificação social nas residências e o "ser quase da família". Para Lukács (2013), as ideologias ditam o modo pelo qual os conflitos cotidianos são percebidos, e isso pode ser aplicado em Que horas ela volta?, quando Val repreende a filha por se sentar na mesa dos patrões e tomar o sorvete deles, isto é, mais uma confirmação de que a doméstica tem consciência de sua posição na casa. Segundo Ferraz et al (2017):

Para Val, tomar um sorvete ou se sentar em uma mesa diferente da dos patrões é algo cotidiano que repõe as subjetividades postas. É a prática que realimenta a ideia que Ihe foi ensinada de subalternidade, ainda, e justamente, permeada de afetividade. (FERRAZ et al, 2017:270) 
No caso de Roma, o uso da luz elétrica no quarto de Cleo é repreendido pelos patrões. Bourdieu (2008) chama de "violência simbólica" esses pequenos atos rotineiros que servem para segregar os indivíduos que fazem parte de um mesmo núcleo. Essa violência não é explícita, isto é, encontra-se disfarçada dentro das relações coloquiais entre patrão e empregado.

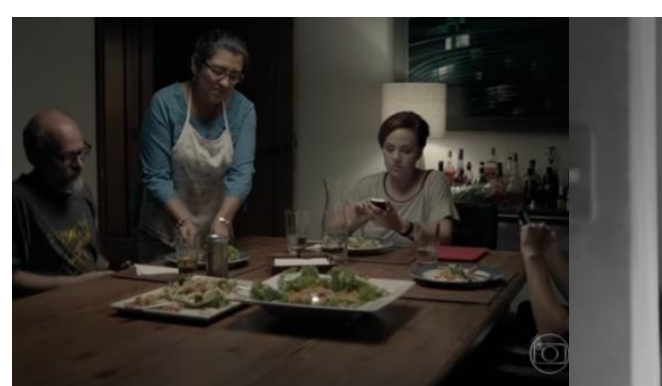

Figura 13 - Relações de poder à mesa. Fonte: Que horas ela volta?, 2015.

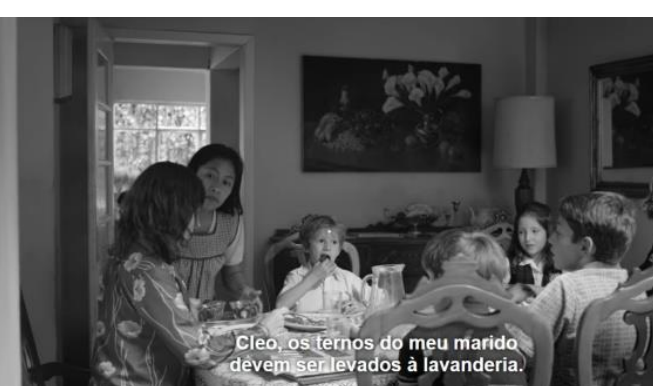

Figura 14 - Relações de poder à mesa.

Fonte: Roma, 2018.

A violência invisível traduzida nessas obras fílmicas por meio de artefatos alegóricos como o conjunto de xícaras; o sorvete; a luz elétrica; o lugar para se sentar, dentre outros, implica na percepção simbólica do outro acerca de uma funcionária doméstica.

Diante de uma rotina exaustiva e das formas de tratamento que tendem à submissão elencadas até aqui, é natural que as personagens domésticas busquem algum tipo de escapismo - o que, segundo Freud (2010), é uma ação necessária para contrabalancear as dores da vida. Para isso, os seres humanos fogem da realidade por diferentes formas - dentre elas, dedicando-se às atividades que os dão prazer ou vivendo momentos lúdicos e de diversão (FREUD, 2010). Em Que horas ela volta?, Val pausa suas tarefas para tomar um banho de sol na área de serviço, onde se localizam os varais (Figura 17). Cleo também utiliza como espaço de escapismo o terraço para lavar as roupas. Entretanto, faz uso do recurso da imaginação como instrumento de fuga ao fingir que está morta em uma brincadeira com Pepe, um dos filhos dos patrões (Figura 18). 


\section{rebeca}
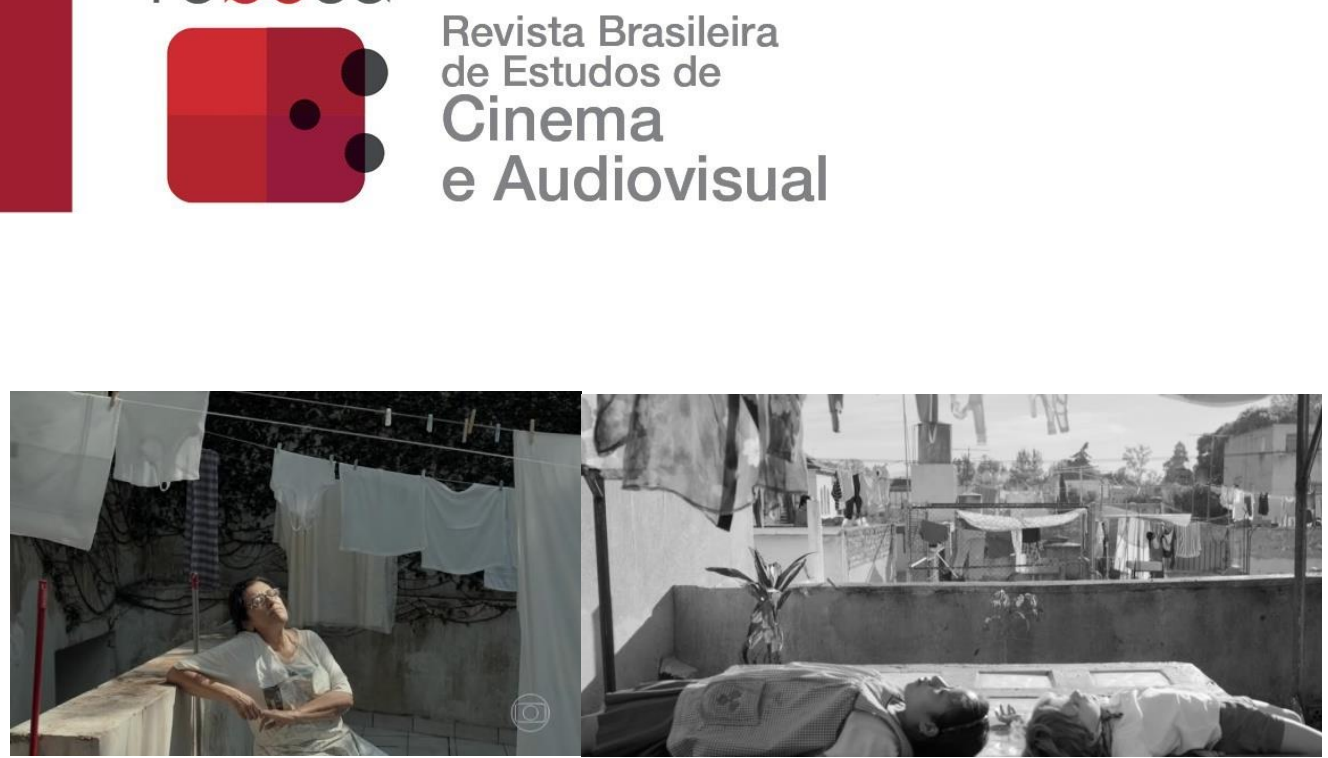

Figura 15 - Escapismo na área de serviço.

Fonte: Que horas ela volta?, 2015.

Figura 16 - Escapismo na área de serviço

Fonte: Roma, 2018.

\subsection{A relação de proximidade entre patrões e empregados}

Por residirem na mesma casa, a relação entre patrões e empregados em Que horas ela volta? e Roma é supostamente constituída de intimidade, visto que é na cotidianidade familiar, segundo Martín-Barbero (1987), que os indivíduos conseguem se despir e ser quem realmente são. A proximidade do patrão com a empregada, em ambas as narrativas, é expressa pelo uso dos apelidos Cleo e Val. ${ }^{6}$ No entanto, enquanto o chefe se dirige ao funcionário de forma íntima, a mesma regra não é válida para o contrário, visto que as protagonistas chamam os patrões não só pelo nome, mas fazem uso dos tratamentos "seu"; "doutor" e "dona", o que reforça a hierarquia e provoca o distanciamento.

O mesmo vale para a negligência com a vida pessoal da doméstica. Enquanto Cleo e Val se interessam e se envolvem com os problemas dos patrões, a recíproca não se faz verdadeira. Em Que horas ela volta?, ao comunicar a Bárbara sobre a chegada da filha, a patroa pergunta à empregada: "Quem é Jéssica?". A incúria se repete em Roma, no momento em que Cleo chega ao hospital para dar à luz e Teresa não sabe informar à recepcionista o nome completo e nem a idade da funcionária. Considera-se, portanto, que os filmes apresentam uma falsa relação de intimidade e afeto entre chefe e empregado.

As relações entre as domésticas e os filhos das patroas, entretanto, são exceções. Ambas as narrativas expressam um amor genuíno construído entre Cleo e Val com as respectivas crianças e, nestes casos, há reciprocidade. Fabinho, por diversas vezes, demonstra mais apego por Val do que pela própria mãe; e Cleo, por sua vez, ouviu "eu te amo" da filha de Sofia. As figuras 19 e 20 demonstram que as tarefas de colocar os filhos das patroas para dormir e acordar vão além de um trabalho, pois envolvem afeto e uma dedicação espontânea por parte das domésticas.

${ }^{6}$ Cleo é apelido de Cleodegária. O nome original de Val não é mencionado - entretanto, supõe-se que seja o apelido de nomes como Valéria, Valquíria ou Valdirene. 


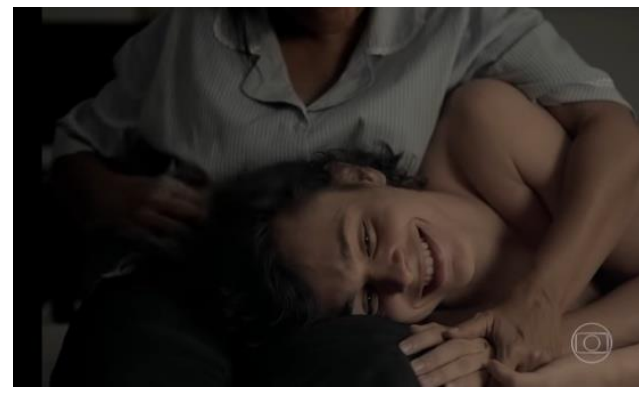

Figura 19 - Val e o filho da patroa.

Fonte: Que horas ela volta?, 2015

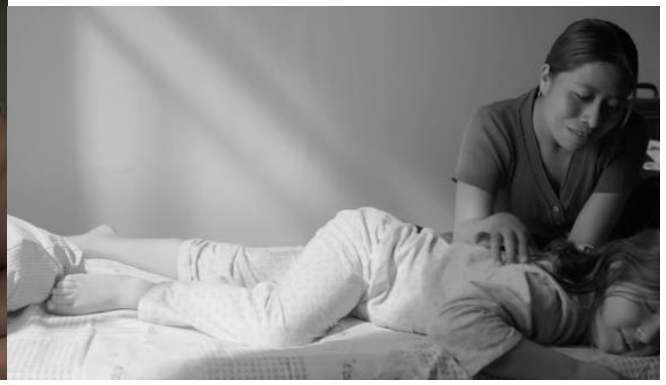

Figura 20 - Cleo e a filha da patroa.

Fonte: Roma, 2018.

A maternidade é uma das temáticas mais emblemáticas das obras fílmicas em análise neste artigo, ao ponto que as reviravoltas das duas narrativas acontecem com a chegada de filhos. Val tem o desafio de cuidar de uma filha que pouco conhece, ao passo que Cleo necessita lidar com uma gravidez inesperada. A ausência da figura paterna é outro elemento compartilhado pelas narrativas. Outro aspecto referente à maternidade é a doação realizada por meio da criação terceirizada. Val e Cleo, mesmo que de diferentes modos, não tiveram a oportunidade de ver seus filhos crescendo e transferem suas competências assistenciais para outras crianças.

Apesar do abismo social representado em ambas as tramas, as domésticas apresentam características em comum com suas patroas. No caso de Val, o ponto de convergência se dá no ato de abdicar da criação dos filhos em prol do trabalho. O filme começa com Fabinho, ainda criança, perguntando a Val que horas a mãe, Bárbara, iria voltar para a casa. No fim, é Jéssica quem relata a Val que, quando criança, perguntava com frequência à tia a que horas a mãe iria retornar. Desta forma, tanto Val quanto Bárbara se abstiveram de criar os próprios filhos, deixando os mesmos aos cuidados de outra pessoa. Já a ligação entre Cleo e sua patroa, Sofia, é o fato de ambas terem sido abandonadas pelos cônjuges durante a narrativa, compartilhando o sentimento de desamparo parental.

No que tange aos personagens masculinos, em ambos os filmes, os mesmos encontram-se em segundo plano. Carlos, chefe de família em Que horas ela volta?, e Antonio, em Roma, são dois personagens passivos, que demonstram pouca preocupação com o núcleo familiar ao qual pertencem, o que engloba principalmente a indiferença para com os filhos e as esposas. Outra característica em comum desses personagens é a infidelidade. Antonio se envolve com outra mulher, mesmo estando casado, enquanto Carlos se interessa por Jéssica, filha de Val. Neste último caso, não houve reciprocidade e, por esta razão, as tentativas de aproximação podem ser percebidas como assédio sexual. 
A respeito do assédio, de acordo com Lana (2016), o fato de Carlos estar no topo da hierarquia social e familiar the concede um sentimento de poder e implica na ausência de limites, sobretudo na lida com mulheres socioeconomicamente desprivilegiadas, reforçando seu status (Figura 21). Pamplona Filho (2002), no entanto, salienta que o assédio é capaz de ser proveniente de inúmeras razões, afetando todo o tipo de mulher. Tendo isso em vista, observa-se que, em Roma, Sofia enfrenta uma situação de assédio: em uma viagem de fim de ano, um homem tenta se aproximar dela ao perceber a fragilidade da mulher diante da ausência do marido. A mesma se afasta imediatamente ao toque dele, configurando a situação como assédio (Figura 22).

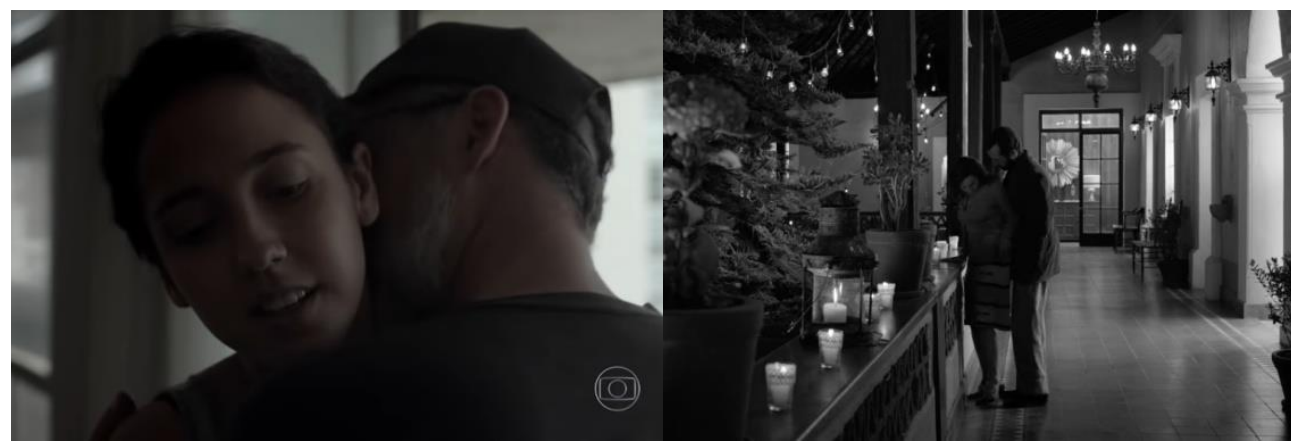

Figura 21 - Assédio sofrido por Jéssica. Fonte: Que horas ela volta?, 2015.

Figura 22: Assédio sofrido por Sofia. Fonte: Roma, 2018.

\subsection{O contraste como elemento simbólico de apontamento das diferenças}

O contraste é um recurso cinematográfico utilizado para transmitir mensagens de cunho implícito ao espectador, além de ser um método de montagem que oferece uma multiplicidade de sentidos. De acordo com Pudovkin (1983: 42), "quanto mais ricos os contrastes, mais satisfação se pode extrair da presença simultânea em diversos ambientes". Que horas ela volta? e Roma são obras que, de maneiras distintas, fazem uso desse artifício.

O contraste se faz presente, inicialmente, pela construção das personagens, visto que as tramas envolvem as relações antagônicas e a estratificação social existente entre patrões e empregados. Em "Que horas ela volta?", Muylaert faz uso de um conjunto de xícaras para representar as diferenças sociais que o filme trata. O presente de aniversário que Val dá a Bárbara é composto por peças pretas e brancas que, desde a embalagem, demonstra a proposta estética de misturar as cores opostas (Figura 23).

A disposição dos pratos e xícaras em preto e branco também abre a possibilidade para mais uma interpretação: a mudança de paradigmas de Val. Quando a protagonista pede demissão e se muda para a sua própria casa, confessa a Jéssica que roubou o presente que havia dado para a patroa. Sobre o jogo de xícaras, Val o 
descreve: "é o preto no branco, é o branco no preto. É diferente que nem tu, é moderno". Ao inserir o artefato em sua casa, é como se Val aceitasse a filha e sua própria mudança, rompendo os limites antes estabelecidos. De acordo com Mattos (2015): "é como um adeus [...] à preocupação em agradar a qualquer preço".

Em Roma, o contraste se faz presente em inúmeras situações, a começar pela fotografia em preto e branco. O comportamento dos personagens em cena também surge de forma contrastante, como por exemplo, quando Sofia entra na garagem dirigindo o automóvel de forma irregular, quebrando o veículo e o muro da casa. Enquanto a patroa demonstra toda a sua instabilidade, Cleo assiste à cena sem se abalar, como se nada estivesse acontecendo.

Uma situação semelhante ocorre quando a doméstica está prestes a dar à luz. No carro e em direção ao hospital, Cleo expressa o sentimento de dor, e Teresa, que a acompanha, deixa claro o seu nervosismo diante da situação. $O$ ambiente externo contribui, pois neste momento ocorria a manifestação estudantil. $O$ ponto de contraste à cena com diversos elementos agonizantes é o motorista do automóvel, que mesmo diante do cenário de instabilidade que o cerca, não expressa reação alguma (Figura 24). Estes exemplos demonstram, portanto, a polarização do caos e do silêncio ${ }^{7}$.

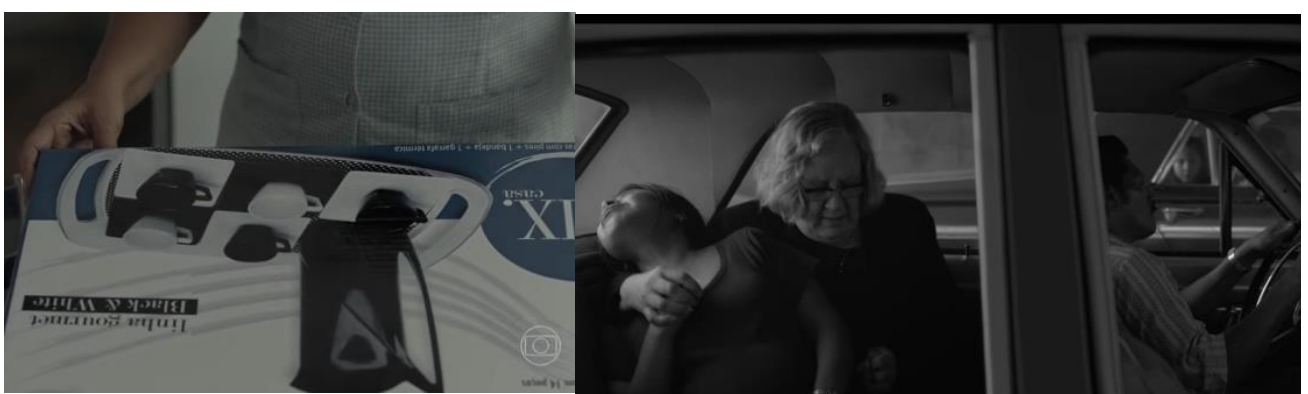

Figura 23 - O contraste nas cores do jogo.

Fonte: Que horas ela volta?, 2015.
Figura 24 - O contraste na reação dos personagens.

Fonte: Roma, 2018.

\subsection{A água como elemento simbólico nas narrativas investigadas}

Um elemento importante e que se faz presente em ambas as obras fílmicas é a água, podendo esta ser analisada de forma simbólica. Para Pudovkin (1983), o simbolismo é uma técnica de montagem cinematográfica eficiente por introduzir uma mensagem de maneira abstrata na mente do espectador. Sobre o simbolismo da água, Bruni (1994) explica:

[...] se levarmos em consideração o papel que a água desempenha nas mais variadas culturas humanas, nas religiões, nas cosmogonias, nos mitos, nas artes, nas literaturas, e na própria filosofia, abre-se perante nós toda

\footnotetext{
${ }^{7}$ Há ainda o contraste entre alegria e tristeza tratados no item 2 (Fotograma 10).
} 
uma outra perspectiva em que a água deixa de ser apenas parte fundamental da natureza externa e da vida biológica para tornar-se dimensão essencial da vida especificamente humana. Isto é, é na dimensão simbólica que a água diz respeito mais profundamente à vida e ao homem. (BRUNI, 1994: 57)

No ambiente urbano onde se ambientam as narrativas investigadas, a água ocupa um lugar importante. Em Que horas ela volta? o elemento serve como instrumento de segregação, dado que a piscina é um local restrito aos patrões. Há um momento em que Jéssica sugere entrar na piscina e é imediatamente repreendida por Val, todavia, Fabinho, em uma brincadeira, joga a filha da empregada na água e eles se divertem na área de lazer. Ao saber que Jéssica utilizou a piscina, Bárbara solicita a limpeza do local, alegando como justificativa a presença de ratos. Val, por sua vez, também aparece em contato com a água, mas no seu caso, se restringe ao uso da mesma para fins de limpeza, como a higienização das louças na pia (Figura 25). Nesse sentido, para os patrões, a água está relacionada à diversão; para os empregados, ao trabalho.

No caso de Roma, a utilização da água na ilustração do serviço de Cleo também é recorrente (Figura 26). Além das cenas em que a empregada aparece limpando o chão ou lavando a louça, em quase todos os ambientes pelos quais ela percorre, poças d'água surgem pelo caminho. Neste filme, a água serve ainda como um elemento de contraste e também aponta a estratificação social. Quando Cleo decide ir à busca de Férmin para falar sobre a criança que espera, visita um bairro simples e precário. No local, um carro transita com uma caixa de som que relata à população sobre a escassez de água enfrentada no povoado. Este cenário se opõe à abundância de água em Roma, bairro que a doméstica trabalha.

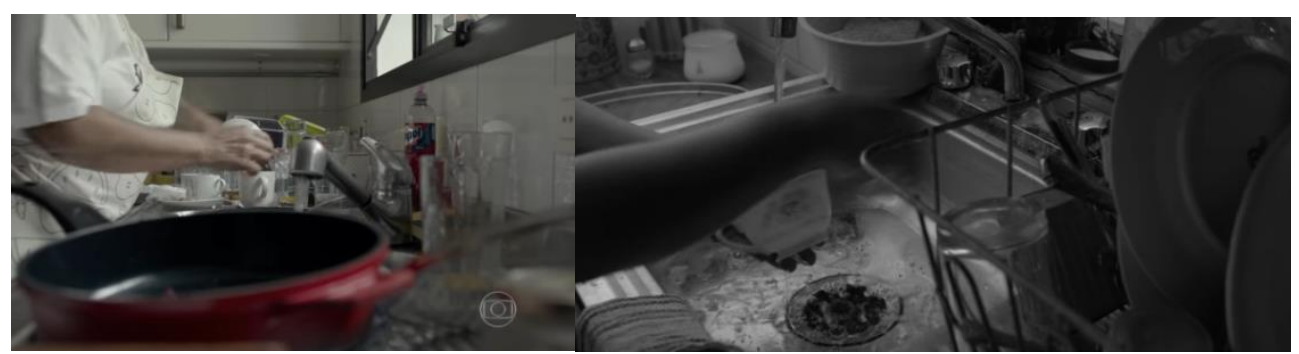

Figura 25 - Close em Val lavando a louça. Fonte: Que horas ela volta?, 2015.

Figura 26 - Close em Cleo lavando a louça. Fonte: Roma, 2018.

Outra situação em que a água se apresenta de forma metafórica é o momento de catarse vivido por Val e Cleo no fim das narrativas. Diante de todos os conflitos enfrentados, é na água que as duas protagonistas decidem romper com suas crenças e limites. No caso de Val, a catarse ocorre na piscina dos patrões, local até então restrito 
a entrada da funcionária (Figura 27), algo mencionado desde a primeira cena, quando a empregada vigiava Fabinho nadando, ainda criança, o observando apenas do lado de fora; no caso de Cleo, o mar, visto que a jovem não sabia nadar (Figura 28).

A motivação que as levou ao ato foi o amor, um sentimento maior que o medo. Diel (1966: 37-38) estabelece um diálogo com a passagem de ambas ao dizer que o elemento é "a purificação pela compreensão, até a mais espiritual de suas formas, pela luz e pela verdade, ao passo que a água simboliza a purificação do desejo, até a mais sublime das suas formas - a bondade".

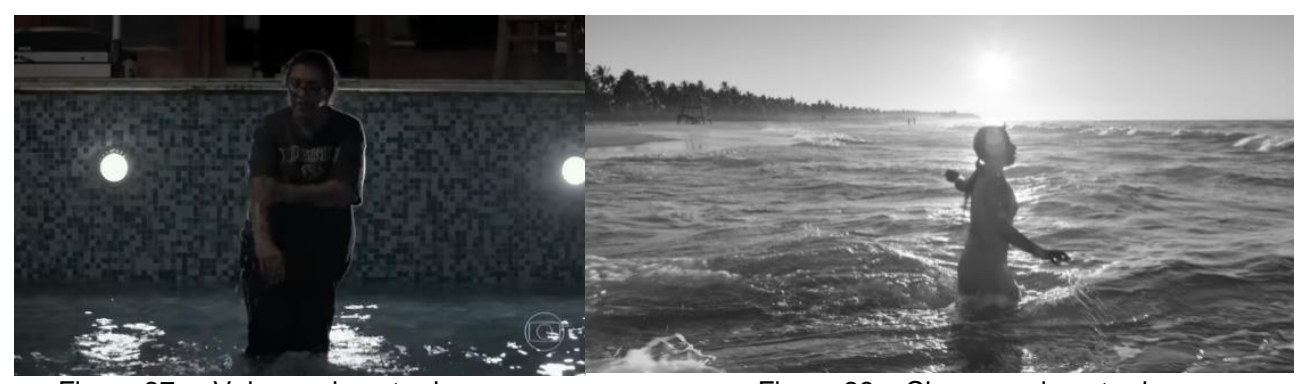

Figura 27 - Val: rompimento de crenças.

Fonte: Que horas ela volta?, 2015.

Figura 28 - Cleo: rompimento de crenças.

Fonte: Roma, 2018.

Observa-se, portanto, que do início ao fim, ambos os filmes utilizam a água como um importante elemento simbólico, seja como uma via sinuosa para assinalar as desigualdades sociais ou como um instrumento de purificação.

\section{Considerações finais}

Que horas ela volta? e Roma são filmes que traduzem fragmentos políticos e sociais de mais de uma época, indo além do momento histórico da narrativa. A obra cinematográfica nacional retrata o Brasil do século XXI - entretanto, abarca elementos que foram herdados de séculos anteriores, sobretudo do período da escravidão. $O$ longa-metragem mexicano, por sua vez, se passa no século XX. Contudo, aborda temáticas que são discutidas até os dias atuais, como a monoparentalidade feminina.

Ambos os filmes obtiveram destaque na cena audiovisual internacional por enfatizarem a figura da empregada doméstica, que normalmente ocupa um espaço ínfimo nas narrativas tradicionais, provocando inquietudes e reflexões nos espectadores acerca da estratificação social e da violência simbólica que ocorre no espaço doméstico.

As investigações das duas obras fílmicas apontam para características culturais semelhantes entre Brasil e México, como a presença da empregada doméstica nos lares de famílias de classes média e alta. Além disso, ambas as obras apresentam, mesmo que de forma implícita, o retrato político das respectivas nações. Ao analisar a cena 
histórica, nota-se que esses países da América Latina, assim como os demais, apresentam traços socioculturais que vieram em decorrência da sua formação política.

Tanto o Brasil quanto o México são historicamente marcados pela desigualdade, por governos que não privilegiaram os mais necessitados, pelos regimes ditatoriais e a estratificação no microcosmo doméstico é um dos resultados desse processo.

Por fim, os filmes demonstram a eficiência na utilização dos elementos simbólicos como um recurso cinematográfico, por exemplo, a presença metafórica da água, sobretudo nas cenas de rompimento de paradigmas. Apesar de toda a atenção destinada às empregadas domésticas nas narrativas, percebe-se que a representação da realidade se mantém na hipocrisia das relações dos patrões, algo presente dentro e fora da tela desde o passado até os dias atuais.

\section{Referências}

ALMEIDA, Paula Alves de; ALVES, José Eustáqui Diniz; da SILVA, José Jaime. "Uma análise demográfica do filme Que horas ela volta?". In: Anais do XX Encontro Nacional de Estudos Populacionais. ABEP - Associação Brasileira de Estudos Populacionais, $2017 . \quad$ Disponível em: http://www.abep.org.br/publicacoes/index.php/anais/article/view/2593 . Acesso em: 29 jul. 2019.

BAUMAN, Zygmunt. O mal-estar da pós-modernidade. Rio de Janeiro: Jorge Zahar Ed., 1998.

BERNARDI, Bruno Boti. "Política externa e direitos humanos no México (2000-2010): avanços externos e fracassos domésticos". Meridiano, vol. 11, n. 122, nov-dez. 2010.

BRINKMAN-CLARK, William. "Roma: Una arquitectura de la memória". Bitácora Arquitectura, Universidad Nacional Autónoma de México. N.40, jul-nov. 2018. Disponível em: http://www.revistas.unam.mx/index.php/bitacora/article/view/69448. Acesso em: 12 jul. 2019.

BRITES, J. "Afeto e desigualdade: gênero, geração e classe entre empregadas domésticas e seus empregadores". Cadernos Pagu, no 29, 2007:91-109.

BRUNI, José Carlos. "A água e a vida". Tempo Social; Rev. Sociol. USP, S. Paulo, 5 (12): 53-65, 1994. Disponível em: http://www.scielo.br/pdf/ts/v5n1-2/0103-2070-ts-05-020053.pdf. Acesso em: 23 jul. 2019.

BOURDIEU: A distinção: crítica social do julgamento. Porto Alegre: Zouk, 2008.

COELHO, Maria Claudia. "Sobre agradecimentos e desagrados: trocas materiais, relações hierárquicas e sentimentos". In: VELHO, Gilberto; KUSCHNIR, Karina (orgs.). Mediação, Cultura e Política. Rio de Janeiro: Aeroplano, 2001. p. 267-291.

DERRIDA, Jacques. A escritura e a diferença. Trad. Maria Beatriz M. Nizza da Silva. São Paulo: Perspectiva, 1971.

DIAS, Luciana de Oliveira. "Seguir adelante: trânsitos identitários entre as/os Mazahuas na Cidade do México". In: SACCHI, Ângela; GRAMKOW, Márcia Maria. (Org.). Gênero e povos indígenas. Brasília: Museu do İndio/GIZ/FUNAI, 2012.

DIEL, Paul. Le symbolisme dans la mythologie grècque. Paris, Payot, 1966. 
FERRAZ, D.L.S. "Pelo fim da categoria inclusão/exclusão: a questão do exército de reserva no capitalismo contemporâneo". In: CATTANI, A. D.; DÍAZ, L. M.; COHEN, N. (Orgs.). A construção da sociedade justa na América Latina. Porto Alegre: Tomo Editorial, 2013. p. 1-20.

FERRAZ, Deise Luiza da Silva. MOURA-PAULA, Marcos. BIONDINI, Bárbara Katherine Faris. MORAES, Aline Fábia Guerra de. "Ideologia, Subjetividade e Afetividade nas relações de trabalho: Análise do filme 'Que horas ela volta?'. Revista Brasileira De Estudos Organizacionais, v. 4. n. 1: 252-278, jun. 2017.

FREUD, Sigmund. "O mal-estar na civilização". Tradução de Paulo César de Souza. In: Obras Completas. Vol. XVIII. Rio de Janeiro: Companhia das Letras, 2010.

FREYRE, Gilberto. Sobrados e mucambos: decadência do patriarcado rural e desenvolvimento do urbano. São Paulo: Global, 2012.

GONÇALVES, Thomás Gomes. "Negação da gravidez: um estudo psicanalítico". Psicologia em Estudo. v. 20, n. 1, 2015. Disponível em: http://www.periodicos.uem.br/ojs/index.php/PsicolEstud/article/view/25657/pdf_20.

GUARNICA, Omar Cerrillo. "Roma: a Portrait of Mexican Segregational Society". Art Style - Art\&Culture International Magazine. V.1, Issue 1, mar - 2019: 25-34. Disponível em: https://artstyle.international/issue-1/. Acesso en: 26 jul. 2019.

HAHNER, June. "Mulheres da elite: honra e distinção das famílias". In: PINSKY, Carla; PEDRO, Joana Maria (orgs.). Nova História das Mulheres no Brasil. São Paulo: Editora Contexto, 2013. p.43-64.

LANA, Lígia. "Da porta da cozinha pra lá": gênero e mudança social no filme Que horas ela volta?. Rumores, n. 19, v. 10, janeiro - junho, 2016. Disponível em; http://www.revistas.usp.br/Rumores/article/view/110278. Acesso em: 13 jul. 2019.

LUKÁCS, G. Para uma ontologia do ser social II. São Paulo: Boitempo, 2013.

MAGNO, Maria Ignês Carlos. "Que horas ela volta? Uma crônica cinematográfica". Comunicação \& Educação. Ano XXI, n. 1, 2016. Disponível em: http://www.revistas.usp.br/comueduc/article/view/109376. Acesso em: 29 jul. 2019.

MARTÍN-BARBERO, Jesús. De los medios a las mediaciones: Comunicación, cultura y hegemonía. México: Gustavo Gilli, 1987.

NÁJERA, Stefanía Alba. "Roma y la visibilización del trabajo doméstico". Bordes Revista de Política, Derecho y Sociedad. N.12, febrero-abril, 2019. Disponível em: https://publicaciones.unpaz.edu.ar/OJS/index.php/bordes/article/view/442. Acesso em: 29 jul. 2019.

PAMPLONA FILHO, Rodolfo. "Assédio sexual: questões conceituais". In: JESUS, Damásio Evangelista de; GOMES, Luiz Flávio (Coord.). Assédio Sexual. São Paulo: Saraiva, 2002.

PEREIRA, Rodrigo da Cunha. "A família: estruturação jurídica e psíquica”. In: PEREIRA, Rodrigo da Cunha (Coord.). Direito de Família Contemporâneo: doutrina, jurisprudência, direito comparado e interdisciplinaridade. Belo Horizonte: Del Rey, 1997.

PERES, Maria Angélica de Almeida ; BARREIRA, leda de Alencar. "Significado dos uniformes de enfermeira nos primórdios da enfermagem moderna". Escola Anna Nery Revista de Enfermagem, v. 7, n. 1: 25-38, 2003.

PUDOVKIN, V. "Métodos de tratamento do material (montagem estrutural)". In: XAVIER, Ismail (org.). A experiência do cinema. Rio de Janeiro: Edições Graal: Embrafilme, 1983.

QUE horas ela volta? Dir.: Anna Muylaert. Prod.: Caio Gullane. Brasil, 2015. 
ROMA. Dir.: Alfonso Cuarón. Prod.: Alfonso Cuarón. México/EUA, 2018.

SANTOS, Luciany Aparecida Alves. "Literatura de cordel e migração nordestina: tradição e deslocamento”. Estudos de Literatura Brasileira Contemporânea. №. 35, Universidade de Brasília Brasília, Brasil, 2010.

SCARPELLINI, Marister. CARLOS, Viviani Yoshinaga. "Monoparentalidade feminina e vulnerabilidade social: a realidade de mulheres chefes de família no município de Apucarana". Anais II Simpósio Gênero e Políticas Públicas. Universidade Estadual de Londrina, 18 e 19 de agosto de 2011. Disponível em: http://www.uel.br/eventos/gpp/pages/arquivos/Marister.pdf. Acesso: 11 ago. 2019.

SCHERDIEN, Camila. BORTOLINI, Ana Carolina dos Santos. OLTRAMARI, Andrea Poleto. "Relações de trabalho e cinema: uma análise do filme 'Que horas ela volta?'”. Farol - Revista de Estudos Organizacionais e Sociedade. v. 5 n. 12 , 2018. Disponível em https://revistas.face.ufmg.br/index.php/farol/article/view/3874. Acesso em: 29 jul. 2019.

SOUZA, Jessé. Ralé brasileira: quem é e como vive. Belo Horizonte: UFMG, 2009.

TUFTE ,Thomas. "Televisão, modernidade e vida quotidiana: discussão sobre o trabalho de Roger Silverstone face a diferentes contextos culturais". Intexto, Porto Alegre: UFRGS, v. 2, n. 2: 1-24, julho/dezembro 1997. Disponível em: https://seer.ufrgs.br/intexto/article/view/3366. Acesso em: 29 jul. 2019.

ZABALBEASCOA, Anatxu. “Roma', um filme sobre memórias que tem a casa como protagonista”. El País, dez. 2018. Disponível em: https://brasil.elpais.com/brasil/2018/12/10/cultura/1544462338 986627.html. Acesso em: 10 ago. 2019. 